\title{
Incidence and Duration of Fiscal Crises: Macroeconomic Determinants
}

\author{
Hemantha K. J. Ekanayake ${ }^{1 /}$
}

\begin{abstract}
This paper examines the determinants of the incidence and duration of fiscal crises for a large sample of developed and developing countries using multivariate probit and survival models, for the period from 1975 to 2010. Overall, the findings suggest that most of the economic fundamentals that trigger crises, do not necessarily lengthen the duration of a crisis except for high levels offoreign reserves, which are associated with a lower probability of fiscal crises incidence as well as faster recovery from a crisis. Moreover, the paper argues for greater capital account openness and for inflation targeting regimes, since it identifies these two as important mechanisms through which fiscal discipline can be improved, which, in turn, contributes towards avoiding fiscal crises.
\end{abstract}

JEL Classification: C33, C41, H60, H63

Key Words: Fiscal Crises, Survival Model, Foreign Reserves, Capital Account Openness, Inflation Targeting.

1/ Author wishes to thank Prof. Ragbendra Jha, Prof. Premachandra Athukorala, Dr. Paul Burke, Dr. Roshan Perera, Dr. P.K.G. Harischandra and anonymous reviewers for their valuable comments and support. Corresponding email: hemantha@cbsl.1k 


\section{Introduction}

"Fiscal crisis" is viewed in the literature as an umbrella term for all types of endangered fiscal solvency, including both external and domestic debt defaults. Unlike a financial crisis, a fiscal crisis has the ability to build up in the economy for a long time without being visible. During this suppressed period, it weakens the economy while allowing pressure to build up in the economy. In the end, when the economy has no resistance left, the situation erupts into a full blown fiscal crisis, forcing governments to alter their policies by restructuring public debt or accessing significant external financial support (in most cases sponsored by the IMF) to regain fiscal sustainability (Baldacci, et al. 2011).

The complex nature of fiscal imbalances makes it difficult to identify fiscal crisis episodes using observable data. Early research used public debt defaults or large scale official financing support to identify fiscal crisis events (Pescatori and Sy, 2004, Reinhart and Rogoff, 2010). More recent studies prefer a much broader definition of fiscal crisis, taking government rollover problems into account (Baldacci, et al. 2011). Early studies mainly focused on fiscal variables that are related to solvency and liquidity in explaining the reasons for a fiscal crisis. More recent studies, however, consider a much broader approach and use institutional and political variables to explain the incidence of a fiscal crisis. However, none of these studies has considered the duration of fiscal crises i.e., the time it takes for a crisis-hit country to return to normal levels, and the determinants of the duration of fiscal crises. Priority should be given to preventing crises, yet if a crisis does occur it is also worthwhile to know ways and means to shorten its duration. More recently, among others, Reinhart and Rogoff (2010) and Baldacci, et al. (2011) have provided comprehensive identification of fiscal crises. One distinctive feature of these studies is that they not only identify the onset of crises but also the recovery from crises, which provides an opportunity to analyse crisis incidence as well as crisis duration. This study aims at analysing the incidence and duration of fiscal crises for a sample of 81 countries over about three decades (1975-2010).

The purpose of this study is two-fold. First it identifies the macroeconomic fundamentals (social, economic, and political) that determine the probability of a fiscal crisis. Then it examines the effect of these macroeconomic fundamentals on fiscal crisis duration. This study offers some extensions to the previous studies on fiscal crises. It examines the importance of economic and socio-political variables on fiscal crises using a broader definition of a fiscal crisis which includes near-default events to identify the onset of a fiscal crisis (Baldacci, et al. 2011). Importantly all these variables are taken as five-year averages leading up to the crisis event, to explain how the pressure build-up in the economy could possibly predict the probability of a crisis occurring, as well as its duration. Secondly, and most importantly, this study analyses fiscal crisis duration and 
its determinants, which has not been analysed in the literature previously, to explore the availability of specific policy measures that are necessary to shorten the crisis duration.

Fiscal crisis incidence is analysed by using a multivariate probit regression model and crisis duration is modeled using survival analysis. Based on estimation results, it is evident that some of the variables that significantly reduce the likelihood of a fiscal crisis do not necessarily reduce crisis duration and vice versa. The level of democracy and the age dependency ratio are found to be significant determinants of crisis duration, yet they do not contribute much to crisis incidence analysis. However, the level of foreign reserves of a country has a different effect as it reduces the likelihood of a crisis and shortens crisis duration. Therefore, this study argues that maintaining a high level of foreign reserves is one of the main tools available for policy makers to avoid a fiscal crisis, as well as to ensure an early exit from a fiscal crisis, if one does occur. Moreover, the paper argues for capital account openness and for inflation targeting regimes, since it identifies these two as important mechanisms through which fiscal discipline can be improved, which, in turn, contributes towards avoiding fiscal crises.

The rest of this paper is structured as follows. Section 2 presents an analytical survey of theoretical and empirical literature on the factors that underlie the imbalances causing fiscal crises. Section 3 sets out the empirical approach and Section 4 presents data. Section 5 discusses the results, and Section 6 presents conclusions.

\section{Review of Literature}

A fiscal crisis is generally defined as the failure to meet a principal or interest payment on the due date, resulting in debt defaults/restructuring or accessing official financing (Reinhart and Rogoff, 2011, Baldacci, et al. 2011). When a government is unable to identify a proper combination of expenditure cuts, revenue increases and borrowing, in line with its financial situation, the country's macroeconomic stability will be threatened. The country will eventually go into fiscal distress and, in the end, a fiscal crisis. There are several factors that may cause a country to experience such an event and they may also contribute to the longevity of the crisis. While numerous studies are devoted to analysing the characteristics of a fiscal crisis, including an external and/or domestic debt crisis, the factors behind crisis duration are less closely examined.

Theoretical models explain fiscal crises as a reflection of a country's critical problems of solvency or a minor problem of temporary illiquidity. Early generation models mainly examined sovereign debt crises and explained crises as a "willingness to pay" problem. At times, even when borrowers are solvent, they are reluctant to repay the debt on time if the benefits of a default are higher than its costs (Cole, et al. 1995, Dooley, 2000). 
Unlike commercial debtors, sovereign debtors are immune to legal action and, making use of that immunity, debtor governments are able to make their decisions based on costbenefit analysis. However, the effects from a default, such as a loss of reputation, can have a long lasting impact.

Second-generation models examine debt defaults as an 'ability to pay' problem, more than a 'willingness to pay' issue. The positive net worth of a country can reverse easily due to sudden shocks to its economy. Berg and Sachs (1988) and Agenor and Montiel (1999), among others, argue that the debt crisis of the early 1980s was of this kind. A sharp increase in the world interest rate hit most of the Latin American countries unexpectedly. As a result, some countries had to restructure their debt on an emergency basis, while others sought large-scale financing from the IMF. Obviously, this kind of situation cannot be categorised under willingness to pay. It is rather a problem of reduced ability to pay due to temporary illiquidity.

Another strand of literature explains debt crises as problems of self-fulfilling expectations. This happens when there is a lack of confidence among debt market participants. For example, if the market expects that the government will be unable to roll-over its maturing debt in the future, market participants will be reluctant to buy new debt today and the end result of this process may then be a debt default or restructuring. The Mexican (1994/1995) debt crisis, which could have been avoided by restructuring the composition of the debt from shorter maturity to longer ones, is considered to be of this category (Cole and Kehoe, 1998).

Empirical studies of debt crises have a long history. As is evident in the literature, the causes of fiscal crises are numerous and can even be unforeseen sometimes. The World Bank (2005) decomposes growth of public debt into its main sources, and emphasises that a rising public debt, which might lead a country into a fiscal crisis, is in fact underlined by several other deteriorated macroeconomic fundamentals. A weak fiscal position, in the form of gross debt to GDP ratio, short term debt to reserves, debt to exports or debt to reserves ratio, cannot be the sole factor behind a fiscal crisis. Other macroeconomic fundamentals might mitigate (or trigger) the negative effect of weak fiscal indicators, thereby lowering (or increasing) the probability of a fiscal crisis. Since most of the empirical literature on debt crises focuses mainly on crisis incidence and not on crisis duration, this study uses several hypotheses derived from the related literature on fiscal crisis incidence to identify factors affecting fiscal crisis duration. 
1. The higher the rate of GDP growth, the lower will be the probability of a fiscal crisis.

Existing evidence indicates that there is a negative relation between GDP growth and fiscal crisis. In general, if a country exhibits a better growth performance, it is more likely that the debt stock is serviced properly, avoiding a fiscal crisis. Similarly, it is also argued that governments have no incentives to promote growth when the benefits of improved growth go to creditors in the form of debt service payments. Figure 1 shows the correlation between public debt and GDP growth for selected countries for the year 2008, at the onset of the Global Financial Crisis (GFC). As can be seen, most of the European countries that were experiencing high public debt to GDP ratio and lower GDP growth, went into debt crisis soon after.

Figure 1: Relationship between Economic Growth and Public Debt (Five year averages)

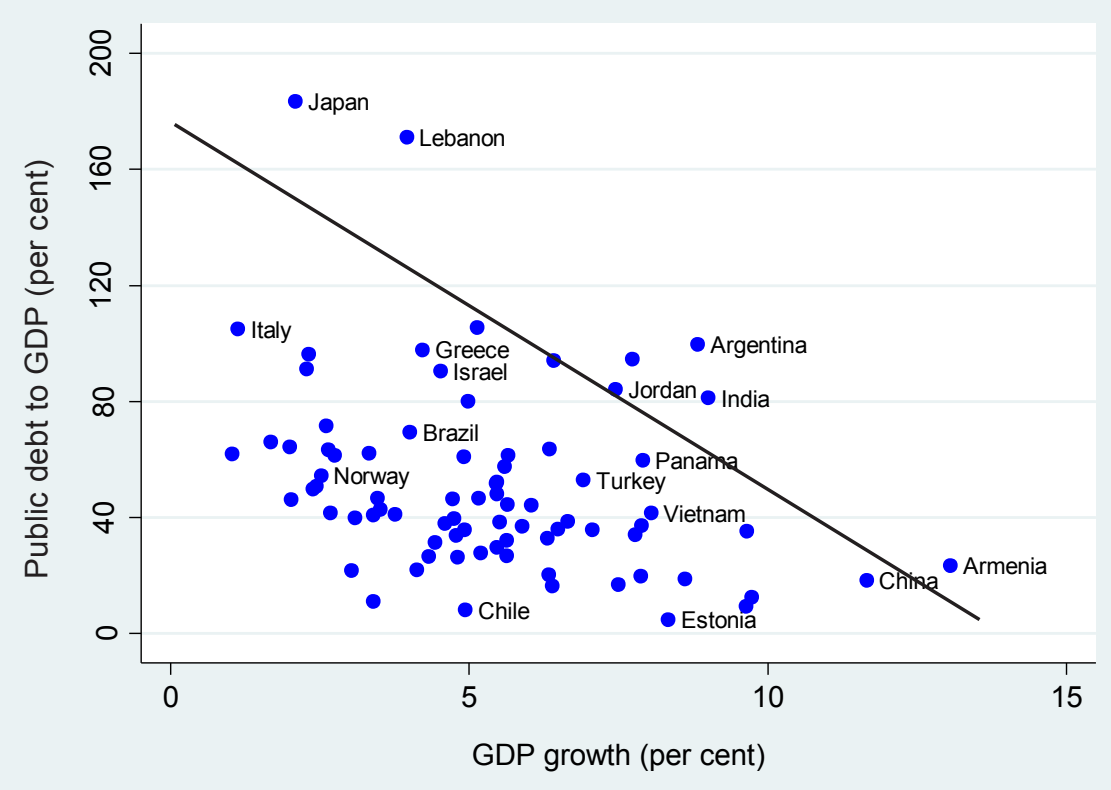

Source: Author's calculations based on World Bank (2011) data

2. The higher the real interest rate, the higher the likelihood of a fiscal crisis.

A rising real interest rate will increase the debt service payment and, as a result, there is a positive correlation between the real interest rate and fiscal crisis. One of the main causes 
of the debt crisis of the 1980s, which badly affected Latin America and Africa, was the real interest rate. During the1980s, most of the loans were made at flexible interest rates and even inflation was unable to bring the real interest rate down and provide automatic debt relief. Rising interest rates have also been identified as one of the main causes of the Euro debt crisis (Schulmeister, 2011).

\section{The higher the level of foreign reserves, the lower the likelihood of a fiscal crisis.}

Traditionally, in countries with fixed, pegged or managed floating exchange rate regimes, accumulation of reserves was necessary to safeguard the exchange rate regime. However, in recent times even countries with floating exchange rate regimes have engaged in building reserves as an insurance against sudden stops or reversals of capital flows and/or to prevent exchange rate appreciation and maintain or promote the country's export competitiveness (Dooley, et al. 2003). ${ }^{2 /}$

4. The greater the capital account openness, the lower the probability of a fiscal crisis.

Capital account openness (CAO) has been debated heavily in the literature on financial crises. Studies point out the importance of CAO in disciplining the fiscal deficit and public spending of a country. It is argued that $\mathrm{CAO}$, which facilitates the globalisation of capital, curtails the ability of governments to pursue economic policies that are either expansionary or more interventionist than global trends (Garrett, 1995 p.663), thereby reducing government spending and any fiscal deficit. Therefore this study aims to identify the impact of $\mathrm{CAO}$ on fiscal crisis occurrence and its duration.

\section{Inflation targeting (IT) reduces the probability of a fiscal crisis occurrence.}

Inflation targeting (IT) has been a widely researched area in macroeconomics. Kumhof, et al. (2007) analyse the balance of payments crisis under an IT regime and find that it is more vulnerable to speculative attacks than other monetary regimes. They explain that "in an open economy, an inflation target always implies a commitment to intervene in the foreign exchange market to defend that target and that commitment could make speculative attacks possible". This study looks at the issue of inflation targeting from a different perspective. The motivation came from Tapsoba (2010), who empirically investigates whether an IT regime improves fiscal discipline, and finds a strong positive effect.

2/ However, reserve accumulation is associated with costs, such as high inflation, higher interest rates and quasi-fiscal costs; therefore, accumulation of reserves is advocated as an expensive yet, potentially useful self-insurance mechanism (Aizenman, 2009) against economic crises. 
It is also argued that under IT there is limited scope for monetising public debt, which, in turn, encourages the government to reinforce its tax collection and rationalise its public expenditure (Minea and Villieu, 2009). Therefore, in line with this reasoning, this paper argues that, if an IT regime makes a country more fiscally disciplined, then there must be a lower probability of a fiscal crisis.

\section{The higher the age dependency ratio, the higher the probability of a fiscal crisis.}

Unlike other economic crises, a fiscal crisis is influenced by the demographic profile of a country. Old age-related spending (health care and pension expenditure) might fuel prevailing fiscal imbalances, threatening fiscal sustainability. Recent studies by Cecchetti, et al. (2010) and Baldacci, et al. (2011) explain the relevance of addressing demographic developments in analysing fiscal imbalances. Eberstadt and Groth (2010) show that during the period 1990-2010, an increase in the old age (65+) share of the total population is associated with an increase in the gross public debt to GDP ratio of about 7 percentage points.

Figure 2: Relationship between Gross Public Debt to GDP Ratio and Age Dependency Ratio

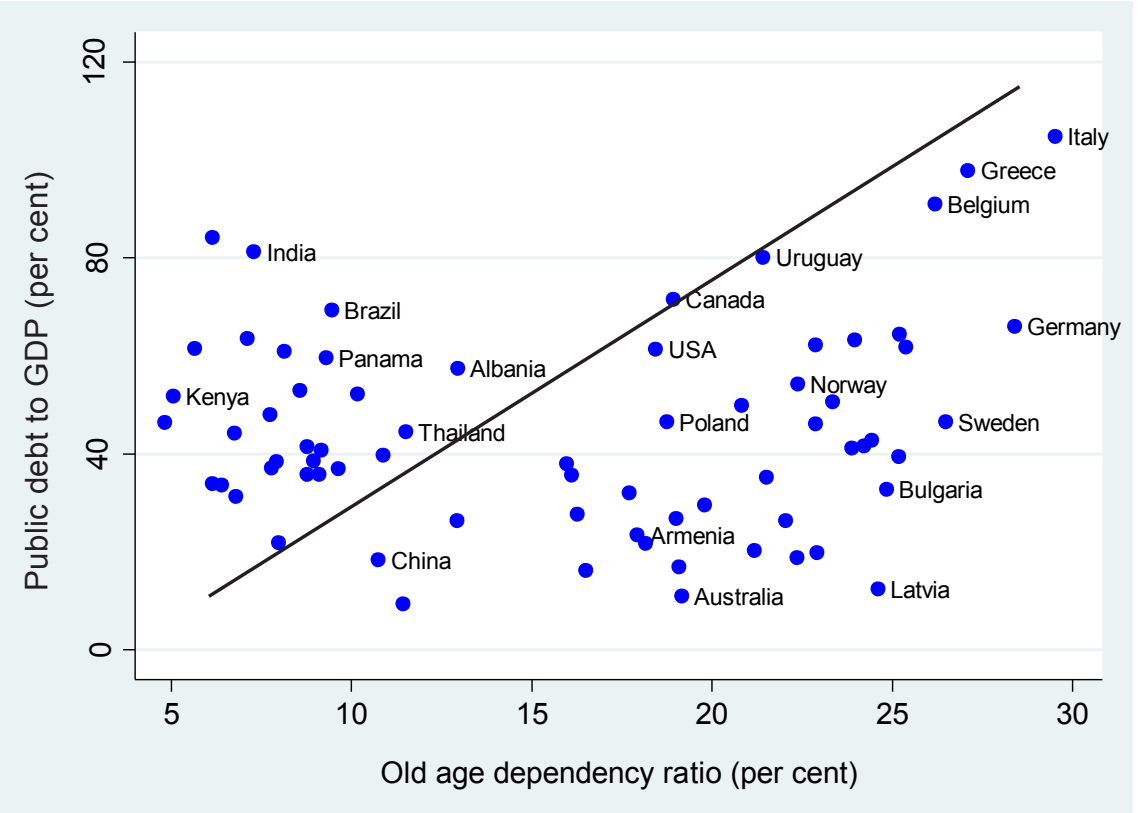

Source: Author's calculations based on World Bank (2011) data 
Figure 2 shows a positive relationship between the two fundamentals for a sample of countries in 2008. Countries located in the top right hand corner (Greece, Italy), have a high old age dependency ratio and experience a higher public debt to GDP ratio. Importantly, these are the countries that experienced a fiscal crisis in 2009/2010.

\section{The more democratic the ruling, the lower the probability of having a fiscal crisis.}

It is irrational to discuss fiscal imbalances without paying attention to the political arena of an economy. Unlike other policies, such as monetary policy, exchange rate policy that are available for macroeconomic management, fiscal policy has a high salience in the electoral sphere, as fiscal policy decisions are immediately visible and directly affect the incomes of voters. In the end, fiscal outcomes might determine the future level of electoral support for the incumbent party. Fiscal policy always faces a democratic dilemma between preferable and effective policy decisions. Cline (1995) explains the importance of political economy factors, such as regime type, rule of law, elections, etc., during the debt crisis and fiscal consolidation periods in developing countries. Among these, regime types and economic policy choices have been debated for a long time. It is argued that democracies are more sensitive to political constraints than to economic constraints, which leads to higher social spending. However, drawing upon the Latin American debt crisis, Remmer (1990) argues that democracies are not only better at avoiding an acute crisis than autocracies, but also handle the crisis better if it occurs.

\section{Estimation of the Model}

\subsection{Fiscal Crisis Incidence}

Limited dependent variable probability models are commonly used in crisis incidence analysis (Kruger and Messmacher, 2004; Kraay and Nehru, 2004; Kohlscheen, 2010). These models account for non-linearity between the cause of a crisis and its eruption. This is an important consideration in the case of crisis incidence analysis, as underlying factors might build up in the economy slowly over time.

$$
\operatorname{Pr}\left\{C I_{t}=1 \mid X_{i}\right\}=F\left(\beta X_{i t}^{\prime}+v_{i t}\right)
$$

In each period a country is either experiencing a crisis or it is not. Therefore, $\mathrm{CI}_{t}$ is a binary variable which takes the value 1 during a crisis and 0 otherwise. The dependent variable ${ }^{3 /}$

3/ To check for robustness, this paper also uses the Reinhart and Rogoff (2010) crisis data set, in which they define debt default as the failure to meet a principal or interest payment on the due date or within the specific grace period, and high inflation as greater than 20 per cent per annum. See Reinhart and Rogoff (2010) for details. 
is obtained from Baldacci, et al. (2011), which defines a fiscal crisis as one or more of the following: public debt defaults/restructuring; the need to access large scale official IMF support; hyperinflation; and volatility of sovereign bond spreads. $X_{i t}$ is a vector of explanatory variables that capture economic, social and political factors and $\beta$ is a vector of parameters to be estimated. All the explanatory variables are smoothed annually using the previous five years data, to address the possible endogeneity issue. $v_{i t}$ represents the random error term $\mathrm{E}\left(v_{i t}\right)=0$.

Even though the panel nature of the data allows for using a country fixed effect model to examine country-specific dependence in the incidence of fiscal crises, it requires the omission of all the countries that have not experienced a fiscal crisis during the period under consideration. This process produces a biased sample (Greene, 1997; Demirgüc-Kunt and Detragiache, 1998). Therefore, this study does not consider using a fixed effect probability model for the estimation of crisis incidence."

\subsection{Fiscal Crisis Duration}

The determinants of crisis duration are examined by employing survival models. Survival models are primarily used in the field of medical science, bio-statistics, and political science. In economics they were first used in the field of unemployment and strike duration analysis (Kiefer, 1988; Nickell, 1979). Since then, their use has gradually become popular in other areas of economics, where the analysis of duration is a key issue. There are a few papers that use this technique to estimate financial crisis duration (Evrensel, 2008; Deb, 2005), but as yet it has hardly been used in the analysis of fiscal/debt crisis duration.

In survival analysis, the dependent variable measures the time (in days, weeks, or years) elapsed before a certain event occurred in each observation. In the literature this event is called a "failure". ${ }^{5 /}$ In the context of this study, the dependent variable measures the time at which a country first experienced fiscal crisis and the failure means the exit from the crisis. When the failure has not occurred by the end of the study period, either because the crisis is ongoing or to missing data, such observations are right-censored. Unlike other estimation techniques, the survival model treats censored data differently and this is one of the advantages of survival models. A non-parametric survival model, the Kaplan-Meier

4/ This study also implements an instrumental variable estimation (ivprobit) to address the endogeneity issue, even after averaging explanatory variables over the previous five years. There are two main candidates among these variables that can be endogenous to the system, i.e., level of reserves and GDP growth. This study instruments the reserve level for each country by its remittances to GDP level while instrumenting GDP growth of a country by its export partners' growth rates.

5/ Survival analysis used in this study applies the Cox (1972) model, which, by its own nature, does not include any dynamics. Therefore, this study does not attempt to provide any dynamics for the underlying variables. 
$(\mathrm{KM})^{6 /}$ estimator, is normally used to compare survival functions of different sub-groups. This study uses the KM estimator to compare survivor functions (also known as survival functions) of the two sets of country groups. The first group consists of IT and non IT countries, whereas the second group considers experienced countries and non-experienced countries (countries experiencing their first crisis). When there are several covariates and some of these are continuous, regression based survival models are commonly used in the literature. In a similar vein in this study, the Cox (1972) semi-parametric model is applied to estimate the factors affecting duration of a fiscal crisis. The advantage of using the Cox model is that it is not necessary to know the distribution of the dependent variable, as required in parametric survival models. However, it is based on the proportional hazards assumption, which needs to be satisfied to obtain consistent estimators of covariates. In the event that the proportional hazard assumption does not hold, it is necessary to use a stratified Cox model, which relaxes the above assumption.

Let's consider the survival time $T$ as a random variable that has probability distribution $F(t)$ and probability density function $f(t)$. Then the survivor function $S(t)$, which explains the probability of surviving time $t$ or beyond, is given by:

$$
S(t)=P(T>=t)=1-F(t)
$$

Similarly the survivor function estimated by the KM estimator is as follows:

$$
S_{t}=\prod_{j \mid t_{(\mathrm{j})} \leq \mathrm{t}}\left(1-\frac{d_{j}}{n_{j}}\right)
$$

where, $d_{j}$ is the number of failures at time $t_{j}$, and $n_{j}$ is the number of countries not experiencing a failure at that time. The product is taken over all failures until time $t_{j}$. In the context of this study, the KM estimator explains the probability of experiencing a fiscal crisis until a particular year $\left(t_{j}\right)$ for relevant country groups separately. In addition to the survival function, it is also important to know about the hazard function in survival models. In the Cox regression, the hazard function for individual $i$ is modeled as follows:

$$
h_{i}(t)=h_{0}(t) \exp \left(\beta^{T} X_{i}\right)
$$

6/ The Kaplan-Meier estimator is a non-parametric methodology to calculate the probability of survival before the event of interest. These events could be death, recurrence of a disease, duration of employment and so forth. The KM estimator is particularly useful in comparing the survival of two or more groups. The KM curve in this study implies, for each time period (year) on the $\mathrm{X}$ axis, the share of countries that does not exit from the fiscal crisis as of that time. 
Integrating the above, one can obtain the cumulative hazard function and the log of the cumulative hazard function is predicted by the Cox regression:

$$
\log \left[H_{i}(t)\right]=\log H_{0}(t)+\beta^{T} X_{i}
$$

where, $H_{0}(t)$ is the base line hazard function, which gives the hazard for an observation when all $X_{i}$ variables are equal to or re-centered to $0 . \beta$ are estimators and $X_{i}$ is a vector that consists of factors affecting survival time. In the context of this study, the estimated hazard ratio by Cox regression means the probability that variable $X_{i}$ can increase/decrease the likelihood of the crisis exit (failure).

\section{Data}

The data are of annual frequency and cover the period 1975-2010 for 81 countries. The dataset consists of 1,500 observations.

Figure 3: Fiscal Crisis Incidences Over Time

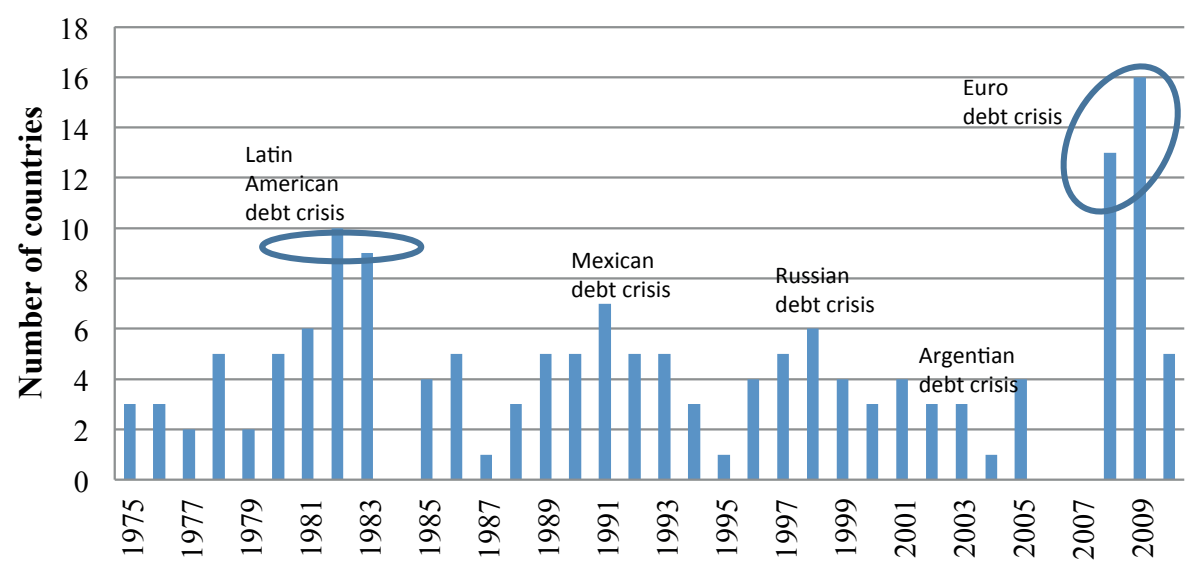

Source: Author's calculations based on Baldacci, et al. (2011)

Data for fiscal crisis incidence and its duration are taken from Baldacci, et al. (2011) and consist of 22 advanced economies and 48 emerging market economies. They also identify 11 countries that have not experienced a fiscal crisis during the study period (Appendix V). Figure 3 illustrates the number of countries in fiscal crisis over the period 1975 to 2010. 
Figure 4 shows the average crisis duration for countries as identified by Baldacci, et al. (2011). It clearly illustrates the cross country variation of fiscal crisis duration. Similarly a single country can also experience different crisis durations at different times.

\section{Figure 4: Variation of the Mean Duration of Fiscal Crisis}

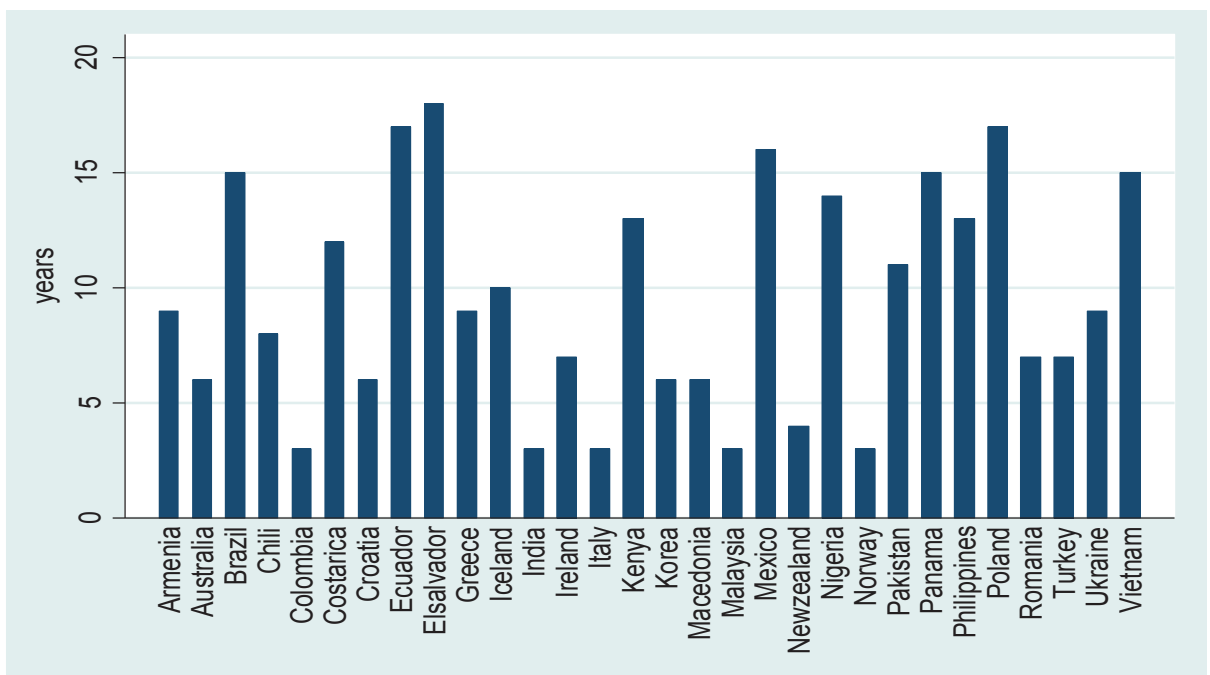

Source: Author's calculations based on Baldacci, et al. (2011)

Data for explanatory variables are taken from different published sources (Appendix I). The capital account openness index is sourced from Chinn and Ito (2008), who construct a capital account openness index for 181 countries since 1970. Limited availability of public debt data has been an issue for a long time. Abbas, et al. (2010) constructed a gross government debt to GDP ratio for almost the entire group of IMF member countries and it is now linked to the IMF World Economic Outlook (WEO) database. Consequently, government debt to GDP data is sourced from WEO (International Monetary Fund 2011).

To represent the impact of political factors on crisis incidence and duration, the democracy variable from the Polity IV project (Marshall, et al. 2008), is used. All the remaining data are from the World Bank's World Development Indicators (World Bank 2011). 


\section{Results}

\subsection{Incidence of Fiscal Crises}

Results of the binary choice (probit) model are presented as marginal effects in Table 1. Marginal effects explain the impact of a unit change in an explanatory variable $\left(X_{i}\right)$ on the probability of observing a fiscal crisis, when all other independent variables are held at their mean. This study uses two different data sets of fiscal crisis incidence, i.e., the IMF (Baldacci, et al. 2011) data set and the RR (Reinhart and Rogoff, 2010) data set, as explained before. Model 1 uses the real interest rate and the GDP growth rate separately, while Model 2 uses the interest growth differential, in the absence of GDP growth and the real interest rate.

Table 1: Determinants of Fiscal Crises: Probit Estimation Results

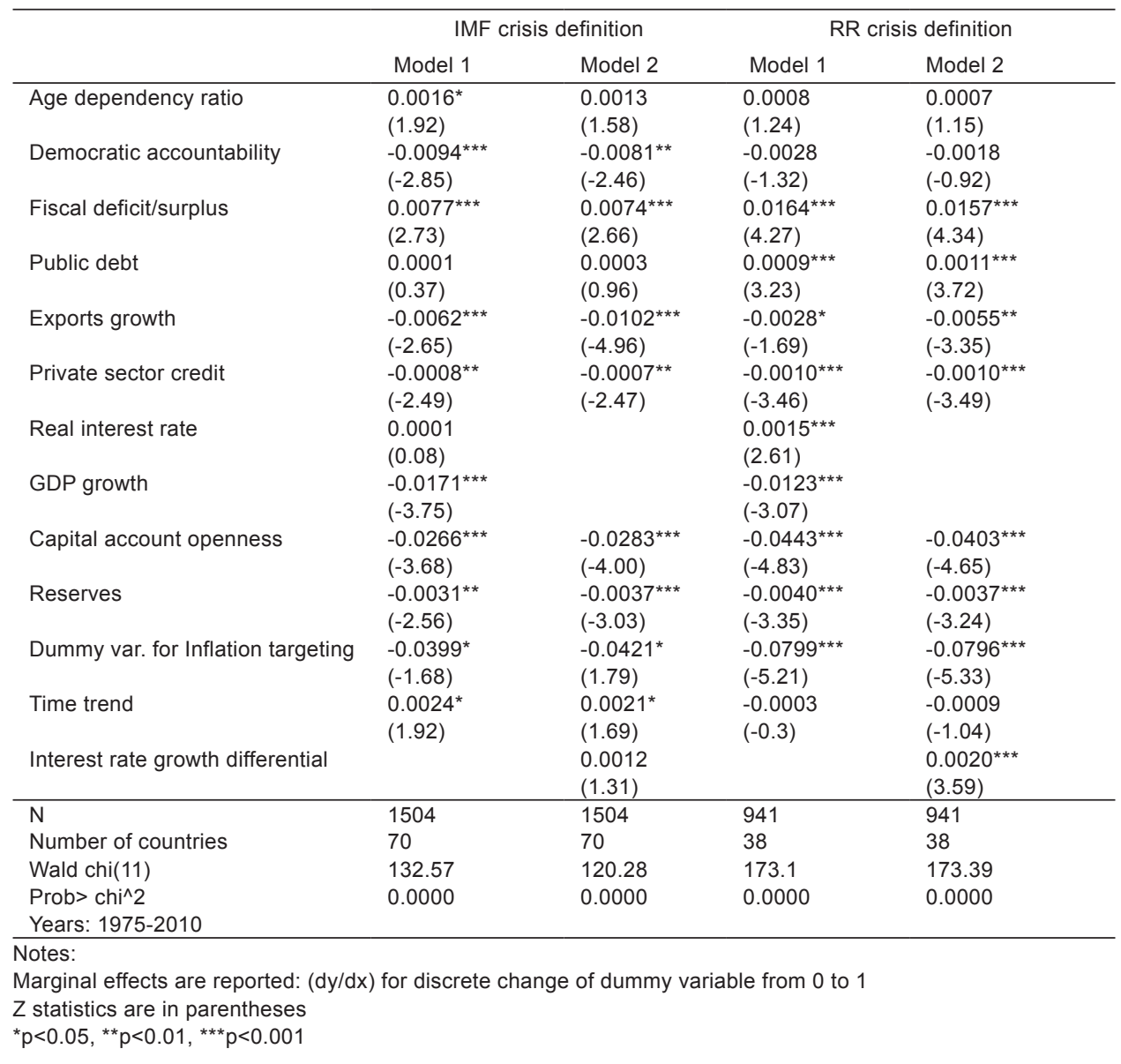


Overall, results show similar patterns irrespective of the crisis definition used. However, to address the possibility of endogeneity between reserves and fiscal crisis incidence, the instrumental variable probit model is estimated. The results (Appendix II) fail to reject the null hypothesis of exogeneity (Wald Test of Exogeneity), which in turn statistically confirms that there is no endogeneity problem among the suspected variables. ${ }^{7 /}$ The results are consistent in the presence of either one or both instrumental variables. Consequently, this study draws conclusions from probit estimation. The coefficients of all variables are with expected signs, even though some of them are not statistically significant. By and large, results confirm the conventional wisdom on the impact of some of the fundamentals on fiscal crisis incidence. They also shed new light on a few other established relationships.

As expected, an increase in fiscal indicators results in increasing the probability of a fiscal crisis. Among the fiscal indicators, only the fiscal deficit (surplus) to GDP ratio provides a consistent relationship over all scenarios. Public debt to GDP becomes significant only under the RR crisis definition. Among the macroeconomic variables, capital account openness, level of international reserves, exports growth and GDP growth significantly reduce the probability of a fiscal crisis. Two institutional variables have been used in the analysis, i.e., domestic credit to GDP ratio to represent the financial development of a country, and a dummy variable for inflation targeting countries to indicate the monetary policy stance of a country. Both these variables indicate a negative and significant relationship with the incidence of fiscal crises.

The level of democracy shows a negative relationship with crisis incidence only under the IMF crisis definition. Similarly, the age dependency ratio shows a positive and significant relationship with the incidence of fiscal crises under the IMF crisis definition. On the other hand, interest rate related variables provide a valid contribution towards explaining the probability of fiscal crisis incidence under the RR crisis definition. What is striking here is that, in this study it is found that some of the results are consistent over all scenarios, indicating the strong validity and robustness of such findings.

The link between inflation targeting and the incidence of fiscal crises has not been studied much in the literature. This study finds that, on average, inflation targeting countries have a lower probability of fiscal crisis. Both crisis definitions confirm this possibility. Only a handful of studies analyse this issue empirically in relation to other types of economic crisis. Among them, Filho (2010) finds that inflation targeting countries dealt better with the recent financial crisis than non-inflation targeting countries, but emphasises the

$7 /$ Not only statistically, but also intuitively, it is reasonable to argue that there is no significant endogeneity issue among these variables. As explained earlier, all the explanatory variables are smoothed annually using previous five-years data and this might eliminate the reverse causality issue thereby mitigating the endogeneity problem. 
necessity of further research to establish the causal link between the two issues. This study provides evidence in support of the hypothesis that argues for a negative link between inflation targeting and crises. However, Kumhof, et al. (2007) argue that inflation targeting countries are vulnerable to speculative attacks.

Another highly debated economic fundamental in relation to crisis incidence is capital market openness. The results indicate that an increase in capital account openness will significantly reduce the probability of a fiscal crisis. As has been explained in earlier sections, capital account openness disciplines fiscal policy and might result in a lower probability of a fiscal crisis by disciplining fiscal policy. A similar result has been found by Vinals (1996), who argues that capital controls facilitate the implementation of expansionary policies by the authorities and can eventually lead to exchange rate market turbulence and a self-fulfilling currency crisis.

The foreign reserves to GDP ratio also significantly reduces the probability of a fiscal crisis, irrespective of the crisis definition used. In recent years, a number of studies have pointed out that there are more costs than benefits of reserve accumulation, which led to another wave of research to analyse the optimal level of reserve accumulation. However, some studies justify reserve accumulation in the context of the self-insurance motive. Based on estimated results, this study argues that a higher level of international reserves, which indicates a country's capacity to face unexpected external financial risks, significantly reduces the probability of a fiscal crisis.

Higher GDP growth and export growth can be considered sound economic fundamentals for a country and have the advantage of reinforcing each other. Therefore, higher levels of these variables increase a country's capacity to mitigate the impact of sudden shocks without entering into a crisis condition. As expected, these variables show a negative relationship with the incidence of fiscal crises. It implies that, on average, a one percentage point increase in GDP growth or export growth is associated with 1.71 percentage points and 0.6 percentage points lower probability of experiencing a fiscal crisis, respectively.

Financial development of a country widens the range of financial services available to the private sector, diversifying risk. To represent such financial development, this study uses the ratio of private sector credit to GDP (Levine, 1998). The results show that an increase in the private sector credit to GDP ratio is associated with a lower probability of a fiscal crisis occurring. One might argue that this result contradicts the experience with the credit bubble situation during the recent GFC, which occurred as a result of an increase in private sector credit due to easy access to financial services. It may be partly true, but it is important to note here that financial development is a much wider concept and consists of the factors, policies, and institutions that lead to effective financial intermediation and 
markets, as well as deep and broad access to capital and financial services. ${ }^{8 /}$ However, there is one distinct feature in the private sector credit to GDP ratio that might be relevant for the discussion. Increasing private sector credit represents decreasing the credit issued to the public sector, including government and government agencies, from the banking sector. Therefore, financial development minimises public intervention in the financial system, improving fiscal discipline, which, in turn, is associated with a lower probability of a fiscal crisis.

An ageing demographic profile is always a concern for governments, as it is closely connected to fiscal expenditure through social security and/or health policies. This study uses the old age dependency ratio to represent the demographic profile of a country and finds that an increase in that ratio is related to a higher probability of a fiscal crisis. However, it turns out to be a significantly important determinant in only one case. Similarly, interest rate related variables provide a positive impact on the occurrence of fiscal crises, as expected from the theory, yet do not consistently become a significant determinant over all cases.

As has been explained earlier, fiscal policy, at times, is stuck between its party constitution and the economic undertakings required to tackle the economic downturn. Using the level of democracy as an explanatory variable of fiscal crisis incidence, this study finds that the higher the level of democracy, the lower is the probability of a fiscal crisis. This result, again, is not consistent over all cases; however, it has not signalled any positive relationship with crisis incidence.

\subsection{Duration of Fiscal Crises}

In an attempt to answer the second question of this study, i.e., what contributes to quicker emergence from a fiscal crisis, survival analysis is employed.

As explained in the methodology section, this study carries out both non-parametric and semi-parametric models of survival analysis. However, this section suffers from a major data limitation. Even though the time period is the same as for crisis incidence analysis, survival analysis only uses data for fiscal crisis episodes. For example, during the period of study (1975-2010), Argentina only provides three observations whereas Mexico provides five. The issue of limited data is made worse by missing data for some explanatory variables. The number of observations for survival analysis has been limited to

8/ The financial development concept goes well beyond the financial depth or credit extended to the private sector (WEF, 2011). The WEF has constructed a comprehensive financial development index for 60 countries since 2008, yet, due to the panel data structure of this study, the index cannot be readily utilised to represent financial development for the empirical estimation. 
75, based on the IMF crisis definition and 35 based on the RR crisis definition. Therefore, conclusions drawn from this section are mainly based on the data from Baldacci, et al. (2011) or the IMF crisis definition. ${ }^{9 /}$

Non-parametric survival analysis calculates the probability of surviving over the last period of time using simple calculus, ignoring the effect of explanatory variables. This study uses Kaplan-Meier (KM) estimates of the survivor function. Table 2 below shows the survival probabilities up to the 10 years duration of the full sample.

\section{Table 2: Kaplan-Meier Estimates of Survivor Function}

\begin{tabular}{cllll}
\hline Time in Years & $\begin{array}{l}\text { Survivor } \\
\text { Function }\end{array}$ & \multicolumn{2}{c}{ [95\% Conf. Int.] } \\
\hline 1 & 0.5029 & 0.4267 & 0.5742 \\
2 & 0.3486 & 0.2788 & 0.4191 \\
3 & 0.2343 & 0.1746 & 0.2992 \\
4 & 0.2057 & 0.1494 & 0.2684 \\
5 & 0.1763 & 0.1239 & 0.2364 \\
6 & 0.1234 & 0.0797 & 0.1773 \\
8 & 0.1104 & 0.0690 & 0.1627 \\
9 & 0.1039 & 0.0638 & 0.1554 \\
10 & 0.0909 & 0.0535 & 0.1405 \\
\hline
\end{tabular}

It shows that there is about a fifty per cent probability that a fiscal crisis lasts for more than a year. However, after the 4th year, the chance of the crisis duration extending to another year is less than 20 per cent. The KM estimator can also be used to compare survivor functions for different groups. These estimated survivor functions then can be tested using the log rank test for equality. If the log rank test rejects the null hypothesis of equal survivor functions for different groups, it confirms that the two survivor functions are significantly different from one another. There are two sets of country groups in this study. The first one, as in the previous analysis, represents inflation targeting (IT) and non-inflation targeting countries. If a country is explicitly targeting inflation on the start year of a crisis it is given 1 while allocating 0 for the rest of the sample.

The second group is constructed on the basis of previous crisis experience of a country. The dummy variable equals 1 if a country has experienced at least one fiscal crisis before and it equals 0 otherwise.

Figure 5 shows the survivor functions for the IT and non IT country groups.

9/ Estimation results based on the RR crisis definition are presented in Appendix IV. 


\section{Figure 5: KM Survivor Functions: IT vs. Non-IT Countries}

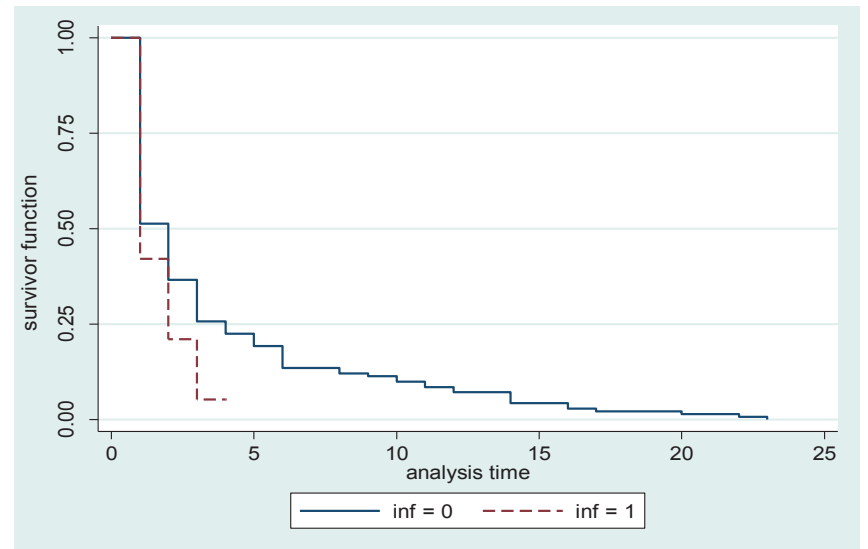

As can be seen, IT countries have emerged from fiscal crises much sooner than non-IT countries. The log rank test also confirms that these two survivor functions are not equal. The result is somewhat convincing, in the sense that the IT countries are more fiscally disciplined than non-IT countries and this might lead to a reduced crisis length. However, it is important to note here that the sub-samples used in this analysis are not balanced. Therefore the result needs to be interpreted cautiously.

\section{Figure 6: KM Survivor Functions for First Time vs. Previously Crisis-Hit Countries}

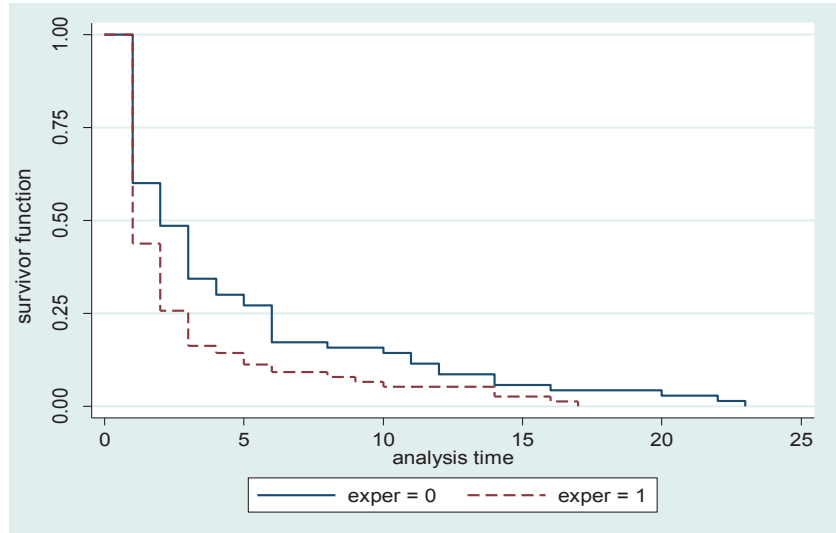


A similar experiment carried out for the second country grouping shows that when a country has previous experience of a crisis, it recovers relatively quicker than a country that faces a crisis for the first time. For example, there is about a 75 per cent probability that a country with previous experience would recover from a fiscal crisis within 2 years. The equivalent probability for a first time country is about 50 per cent (Figure 6). Log rank tests confirm that the two survival functions are significantly different from one another.

A non-parametric survival model only allows, at most, a comparison of survivor functions under different groupings, or, in other words, only uses discrete time explanatory variables. Most of the variables in this study are continuous time and, therefore, to understand the factors affecting the survival function, this study employs a semi-parametric (Cox 1972) survival model for crisis duration analysis. ${ }^{10 /}$

It is more likely that the economic, social and political situations at the time of entering a crisis would contribute to longer or shorter crisis episodes. Therefore, this study uses explanatory variables as at the crisis onset year. However, to be consistent with the previous section (crisis incidence analysis), annual smoothed (five-year) data of the same explanatory variables have also been tested. It is necessary to test the proportional hazard assumption before interpreting the results of semi-parametric analysis, as it is the fundamental assumption of the model.

Table 3: Durational Analysis: Semi-Parametric Model

\begin{tabular}{|c|c|c|}
\hline Explanatory variables & Model 1 & Model 2 \\
\hline Age dependency ratio & $0.9536^{* * *}$ & $0.9578^{* *}$ \\
\hline Democratic accountability & $1.0522^{* * *}$ & $1.0751^{* * *}$ \\
\hline Real interest rate & 0.9961 & 0.997 \\
\hline Fiscal deficit/surplus & 0.9983 & 0.9835 \\
\hline Public debt & 0.9998 & 0.9963 \\
\hline Export growth & $0.9690^{* *}$ & $0.9859^{*}$ \\
\hline Domestic credit & 0.9954 & 0.9972 \\
\hline GDP growth & 0.9597 & 1.0129 \\
\hline Capital account Openness & 0.9943 & $1.1915^{* *}$ \\
\hline Reserves & $1.0249^{* *}$ & $1.0165^{* *}$ \\
\hline World GDP & 1.1092 & 1.0729 \\
\hline $\mathrm{N}$ & 86 & 70 \\
\hline Prob $>\operatorname{chi}^{\wedge} 2$ & 0.0003 & 0.0003 \\
\hline Test of $\mathrm{PH}$ assumption & 0.9879 & 0.9989 \\
\hline \multicolumn{3}{|c|}{$\begin{array}{l}\text { Note: } \\
\text { 1. Model } 1 \text { : Explanatory variables are five-year averages leading to a crisis } \\
\text { Model } 2 \text { : Explanatory variables are annual data at the onset of a crisis } \\
\text { 2. Hazard ratios after survival analysis are reported: } \\
\text { 3. }{ }^{*} p<0.05,{ }^{* *} p<0.01,{ }^{* * *} p<0.001\end{array}$} \\
\hline
\end{tabular}

10/ Similar results are obtained from parametric survival models and are reported in Appendix III. This study relies on semi-parametric models, as they are not dependent on an author-specified distribution function. 
It is found that neither of these models violates the proportional hazard assumption and, consequently, they provide a valid explanation for fiscal crisis duration. As can be seen in Table 3, only a few variables show a significant contribution to fiscal crisis duration, irrespective of the different timing of the explanatory variables. Higher levels of the reserves to GDP ratio and democratic accountability increase the probability of a shorter crisis. In contrast, the age dependency ratio and export growth are significantly associated with slower recovery. Survival model results are reported as hazard ratios. A hazard ratio of 1 means that a change in the independent variable is not associated with any change in the dependent variable (crisis spell), whereas a hazard ratio greater than (smaller than) 1 indicates that an increase in the independent variable is associated with a faster (slower) ending of the crisis. The hazard ratio of 1.0165 in the case of reserves to GDP implies that an increase in the reserves to GDP ratio is associated with a relatively faster ending to the fiscal crisis.

Based on estimation results, reserve accumulation not only acts as insurance that mitigates crisis occurrence, but also works as a shock absorber, reducing the duration of a crisis. There are a number of studies that explain the cost of reserve accumulation and emphasise the importance of knowing the threshold level of reserves for a country. However, none of these studies deny the important role that reserves can play in relation to a crisis. A higher level of democracy is also found to be a significant factor that reduces the duration of a fiscal crisis. This result is in line with studies that argue democratic regimes handle crisis more effectively than autocratic ones.

A higher age dependency ratio contributes to longer fiscal crisis duration (by about 5 per cent). The impact of an ageing society can come in two ways. On the one hand, it is associated with compulsory government expenditure through social security and health payments. On the other hand, the higher age dependency means a smaller workforce, which, in turn, limits the level of available human capital. Therefore, it is more likely that a higher age dependency ratio increases the time needed to recover from a fiscal crisis.

In contrast to conventional wisdom, the results indicate that higher export growth is associated with longer crisis spells. This relationship is consistent over both models and even with different survival model techniques (Appendix IV). In an attempt to explain this result, this study advances the following argument. An increase in export growth, either during the previous five years or in the crisis start year, might imply that country's higher dependence on exports, as well as its greater interactions with the rest of the world. When a crisis hits, the higher export dependence and inability to meet export obligations, can paralyse the economy badly, leading to a slower recovery. Moreover, if a crisis has occurred simultaneously in its trading partners, this situation can be further aggravated. Therefore, at normal times higher export growth reduces the likelihood of a crisis, but in 
a crisis period it might result in a longer crisis. The Latin American experience during the mid-1980s is quite relevant to this issue.

Capital account openness does not provide consistent results over the two specifications and this study leaves further analysis of the relationship between capital account openness and fiscal crisis duration for future research.

\section{Conclusions}

This study analyses the determinants of incidence and duration of fiscal crises using data from 81 countries over the period 1975-2010. The probit model has been used to estimate fiscal crisis incidence and a survival model is employed to estimate the determinants of fiscal crisis duration. This study finds that capital account openness, domestic financial market development, higher reserves to GDP, higher exports to GDP, high GDP growth, democratic accountability, and inflation targeting regimes are all associated with a lower probability of a fiscal crisis. On the other hand, fiscal indicators such as fiscal deficit (surplus) to GDP or public debt to GDP, raise the probability of a fiscal crisis. These results are robust for different definitions of a fiscal crisis. Factors affecting fiscal crisis duration have been analysed using both non-parametric and parametric models. Some evidence has been obtained that the fiscal crisis recovery process is different for IT and non-IT countries. This study finds that IT countries recover sooner from a fiscal crisis than non-IT countries. Similarly, countries with previous crisis experience recover from a fiscal crisis relatively faster. Results from the semi-parametric model show higher levels of reserves and more democratic political regimes lead to a faster recovery from a fiscal crisis, whereas a higher age dependency ratio makes crisis duration longer.

For any economic crisis such as banking, currency or fiscal, the first priority is to take relevant policy actions to avoid its occurrence. However, if a crisis hits an economy, then obviously the next and the most important step should be to shorten the duration and minimise the negative impact. Therefore, it is vital to analyse crisis incidence and duration together, to identify possible factors behind each process, as has been done in this study. Overall, most of these findings are in line with conventional wisdom, even though some new light is shed. More importantly, the highly debated fundamentals in economics, such as reserve accumulation, capital account openness and an inflation targeting regime, are found to be favourable in helping to avoid a fiscal crisis. These findings also reveal the importance of fiscal discipline, which mitigates fiscal imbalances and thereby helps to avoid a fiscal crisis. It is also evident here that economic fundamentals do not affect crisis occurrence and duration in a similar way. Some of the factors, such as demographic profile and level of democracy, are found to be more effective in explaining the duration, 
rather than the incidence of a fiscal crisis, whereas factors like exports to GDP acts in the opposite direction for crisis incidence as opposed to its duration.

In summary, this research first argues that maintaining a higher level of reserve is an optimal policy in relation to a fiscal crisis, as it reduces the likelihood that a crisis will occur and also shortens the duration, if a crisis does happen. This study is well aware of the cost of reserve accumulation and, therefore, an optimal level of reserve hoarding must be identified and it needs to be country specific. Secondly, and perhaps more importantly, this study emphasises the notion of fiscal discipline in relation to fiscal crisis, irrespective of whether it stems from an inflation targeting regime and/or greater capital account openness.

However, there are limitations to this study. The second part is heavily influenced by the small size of the sample and, as a result, robustness checks might not be reliable. Therefore, care must be taken in interpreting inconsistent results (such as sign reversal of CAO) of durational analysis. Furthermore, this study is unable to use some of the comprehensive indices to represent the financial development and/or political stance of a country, due to unavailability of suitable time series data. Even though the panel estimation does not require data over a longer time period, the survival model would have been severely affected if the time period had been any shorter. 


\section{References}

Abbas, A. S., Belhocine, N., ElGanainy, A and Horton, M. (2010). A Historical Public Debt Database, IMF Working Paper, WP/10/245.

Agenor, P. and Montiel. P. J (1999). Development Macroeconomics, Princeton University Press.

Aizenman, J. (2009). Hoarding International Reserves versus a Pigovian Tax-Cum-Subsidy Scheme: Reflections on the Deleveraging Crisis of 2008-9, and A Cost-Benefit Analysis, NBER Working Paper, No. 15484.

Baldacci, E., Belhocine, N., Petrova, I., Dobrescu, G. and Mazraani, S.( 2011). Assessing Fiscal Stress, IMF Working Paper, WP/11/100.

Berg, A. and Sachs, J.(1988). The Debt Crisis Structural Explanations of Country Performance, Journal of Development Economics, 29(3), pp.271-306.

Cecchetti, S. G., Mohanty, M. S. and Zampolli, F. (2010). The Future of Public Debt: Prospects and Implications, BIS Working Papers, No. 300.

Chinn, M. D. and Ito, H. (2008). A New Measure of Financial Openness, Journal of Comparative Policy Analysis, 10(3), pp.309-322.

Cline, W. R. (1995). International Debt Reexamined. Washington, DC: Institute for International Economics.

Cole, H. L. and Kehoe, P. J. (1998). Models of Sovereign Debt: Partial Versus General Reputations, International Economic Review, 39(1), pp.55-70.

Cole, H. L., Dow, J. and English, W. B. (1995). Default, Settlement, and Signalling: Lending Resumption in a Reputational Model of Sovereign Debt, International Economic Review, 36(2), pp.365-385.

Cox, D. R. (1972). Regression Models and Life-Tables, Journal of the Royal Statistical Society. Series B (Methodological), 34(2), pp.187-220.

Deb, S. (2005). Trade First and Trade Fast: A Duration Analysis of Recovery from Currency Crisis, Working Paper, Department of Economics, Rutgers, the State University of New Jersey, No. 2006(07).

Demirgüc-Kunt, A. and Detragiache, E. (1998). The Determinants of Banking Crisis in Developing and Developed Countries, IMF Staff Papers, 45(1), pp.81-109. 
Dooley, M. P. (2000). Debt Management and Crisis in Developing Countries, Journal of Development Economics, 63(1), pp.45-58.

Dooley, M. P., Folkerts-Landau, D. and Garber, P. (2003). An Essay on the Revived Bretton Woods System, NBER Working Paper Series, No. 9971.

Eberstadt, N. and Groth, H. (2010). Demography and Public Debt: The Crisis Beyond, Wall Street Journal forthcoming.

Evrensel, A. Y. (2008). Banking Crisis and Financial Structure: A Survival-Time Analysis, International Review of Economics \& Finance, 17(4), pp.589-602.

Filho, I. E. C. (2010). Inflation Targeting and the Crisis: An Empirical Assessment, IMF Working Papers, WP10(45).

Garrett, G.(1995). Capital Mobility, Trade, and the Domestic Politics of Economic Policy, International Organization, 49(04), pp.657-687.

Greene, W. H. (1997). Econometric Analysis, Prentice Hall.

International Monetary Fund (2011). World Economic Outlook Data Online, http://www.imf.org, accessed various dates.

Kiefer, N. M. (1988). Economic Duration Data and Hazard Functions, Journal of Economic Literature, 26(2), pp.646-679.

Kohlscheen, E. (2010). Domestic vs. External Sovereign Debt Servicing: An Empirical Analysis, International Journal of Finance \& Economics, 15(1), pp.93-103.

Kraay, A. and Nehru, V. (2004). When is External Debt Sustainable?, World Bank Policy Research Working Paper, No. 3200.

Kruger, M. and Messmacher, M. (2004). Sovereign Debt Defaults and Financing Needs, IMF Working Paper, WP/04(53).

Kumhof, M., Li, S. and Yan, I. (2007). Balance of Payments Crises under Inflation Targeting, Journal of International Economics 72(1), pp.242-264.

Levine, R. (1998). Financial Development and Economic Growth: Views and Agenda, Journal of Economic Literature, 35(2), pp.688-726.

Marshall, M. G., Jaggers, K. and Gurr, T.R. (2008). Polity IV Project: Political Regime Characteristics and Transitions, 1800-2008, George Mason University, Colorado State 
University, and University of Maryland. www.systemicpeace.org, accessed various days.

Minea, A. and Villieu, P. (2009). Can Inflation Targeting Promote Institutional Quality in Developing Countries?, The 26th Symposium on Money, Banking and Finance. University of Orléans.

Nickell, S. J. (1979). Estimating the Probability of Leaving Unemployment, Econometrica, 47(5), pp.1249-1266.

Pescatori, A. and Sy, A. N. R. (2004). Debt Crises and the Development of International Capital Markets, IMF Working Paper, No. 04/44.

Rajan, R. G. (2005). Has Financial Development Made the World Riskier?, NBER Working Papers, No. 11728.

Reinhart, C. M. and Rogoff, K. S. (2010). From Financial Crash to Debt Crisis, NBER Working Paper 15795, Forthcoming in American Economic Review.

Reinhart, C. M. and Rogoff, K. S. (2011). A Decade of Debt, National Bureau of Economic Research Working Paper Series, No. 16827.

Remmer, K. L. (1990). Democracy and Economic Crisis: The Latin American Experience, World Politics, 42(03), pp.315-335.

Schulmeister, S. (2011). The European Monetary Fund: A Systemic Problem Needs A Systemic Solution, WIFO Working paper, Australian Institute of Economic Research.

Tapsoba, R. (2010). Does Inflation Targeting Improve Fiscal Discipline? An Empirical Investigation, Working Papers, E201020, Centre d'Études et de Recherches sur le Dévelopement International, France.

Vinals, J. (1996). A Comment: In response to Eichengreen, et al. (1996). In Frankel, J.A., Galli, G. and Giovannini, A. (Eds.), The Microstructure of Foreign Exchange Markets.

WEF (2011). The Financial Development Report, World Economic Forum, USA Inc.

World Bank (2005). Public Debt and Its Determinants in Market Access Countries, International Debt Department, World Bank.

World Bank (2011). World Development Indicators Online, World Bank, USA. http://databank.worldbank.org, accessed various dates. 


\section{Appendix I : Summary Statistics and Data Sources}

\section{Summary Statistics}

\begin{tabular}{lcc}
\hline \multicolumn{1}{c}{ Variable } & Mean & Std. Dev. \\
\hline Age dependency ratio (per cent) & 14.963 & 6.858 \\
Democratic accountability (index) & 7.448 & 3.324 \\
Fiscal deficit/surplus to GDP (per cent) & -2.619 & 4.011 \\
Public debt to GDP (per cent) & 53.990 & 29.881 \\
Exports growth ratio (per cent) & 0.023 & 0.053 \\
Domestic credit to GDP (per cent) & 58.657 & 40.015 \\
Real interest rate (per cent) & 6.114 & 8.972 \\
GDP growth (per cent) & 3.671 & 2.423 \\
Capital account openness (index) & 0.641 & 1.499 \\
Reserves to GDP (per cent) & 10.816 & 12.217 \\
Interest rate growth differential & 2.292 & 9.527 \\
\hline
\end{tabular}

\section{Data sources:}

Fiscal crisis: Baldacci (2011) and Reinhart and Rogoff (2010).

Old age dependency ratio: World Development Indicators (online)

Fiscal surplus/deficit: World Development Indicators (online)

Public debt: World Economic Outlook (online)

Annual growth rate of exports: World Development Indicators (online)

Domestic credit: World Development Indicators (online)

Real interest rate: World Development Indicators (online)

GDP growth: World Development Indicators (online)

Interest rate growth differential: Compiled by the Author using data from World Development Indicators International Reserves: World Development Indicators (online)

Democracy: Polity project, www.systemicpeace.org

Capital account Openness: Chinn and Ito (2008)

Inflation targeting countries: Hammond, G. (2012) 


\section{Appendix II : Instrumental Variable Estimation for IMF Data}

\begin{tabular}{lcc}
\hline & Model 1 & Model 2 \\
\hline Age dependency ratio & -0.001 & 0.001 \\
& $(-0.18)$ & -0.16 \\
Democratic accountability & $-0.078^{* * *}$ & $-0.072^{* * *}$ \\
& $(-3.58)$ & $(-3.25)$ \\
Fiscal deficit/surplus & $0.038^{*}$ & 0.034 \\
Public debt & -1.73 & -1.52 \\
& 0.003 & 0.003 \\
Exports growth & -1.31 & -1.11 \\
& $-0.026^{* *}$ & $-0.027^{* *}$ \\
Domestic credit & $(-2.06)$ & $(-2.09)$ \\
& $-0.003^{* *}$ & -0.003 \\
Capital account openness & $(-2.49)$ & $(-1.18)$ \\
Reserves & -0.04 & -0.032 \\
& $(-0.86)$ & $(-0.67)$ \\
Dummy var. for Inflation targeting & $-0.064^{* * *}$ & $-0.053^{* * *}$ \\
Time trend & $(-3.48)$ & $(-2.86)$ \\
Interest rate growth differential & 0.156 & 0.149 \\
& -0.97 & -0.91 \\
N & $0.025^{*}$ & $0.019^{*}$ \\
Wumber of countries & -2.03 & -1.61 \\
Prob> chi^2 & $0.006^{*}$ & 0.007 \\
& -1.72 & -1.27 \\
\hline
\end{tabular}


Appendix III : Parametric Survival Models with Five Year Averages of Explanatory Variables

\begin{tabular}{l|lllc}
\hline Explanatory variables & Stcox & Streg(exp) & Streg(weibull) & Streg(Gomperz) \\
\hline Age dependency ratio & $0.9536^{* * *}$ & $0.9538^{* * *}$ & $0.9124^{* * *}$ & $0.9325^{* * *}$ \\
Democratic accountability & $1.0522^{* * *}$ & $1.0519^{* * *}$ & $1.1093^{* * *}$ & $1.0872^{* * *}$ \\
Real interest rate & 0.9961 & 0.9948 & 0.9909 & 0.9926 \\
Fiscal deficit/surplus & 0.9983 & 0.9995 & 0.9944 & 0.9877 \\
Public debt & 0.9998 & 0.9995 & 1.0013 & 1.0001 \\
Export growth & $0.9690^{* *}$ & $0.9673^{* * *}$ & $0.9294^{* * *}$ & $0.9477^{* * *}$ \\
Domestic credit & 0.9954 & 0.9952 & 0.9914 & 0.9934 \\
GDP growth & 0.9597 & 0.9567 & 0.9589 & 0.9633 \\
Capital account openness & 0.9943 & 0.9928 & 1.0197 & 1.0033 \\
Reserves & $1.0249^{* *}$ & $1.0242^{* *}$ & $1.0396^{* *}$ & $1.0340^{* *}$ \\
World GDP & 1.1092 & 1.0961 & 1.0092 & 1.0134 \\
\hline $\mathrm{N}$ & 86 & 86 & 86 & 86 \\
Prob> chi^2 & 0.0003 & 0.0001 & 0.0008 & 0.0002 \\
\hline
\end{tabular}

Notes:

1. Hazard ratios after survival analysis are reported:

2. * $p<0.05,{ }^{* *} p<0.01,{ }^{* * *} p<0.001$

\section{Appendix IV : Semi Parametric Survival Analysis: RR Data}

\begin{tabular}{l|ll}
\hline Explanatory variables & Model 1 & Model 2 \\
\hline Age dependency ratio & 1.0345 & 0.9842 \\
Democratic accountability & $1.0781^{* * *}$ & $1.0681^{* *}$ \\
Real interest rate & 1.0032 & 0.9952 \\
Fiscal deficit/surplus & 0.9996 & $0.9372^{* * *}$ \\
Public debt & 1.0102 & 1.0065 \\
Export growth & 0.9949 & $1.0385^{* *}$ \\
Domestic credit & 1.0110 & 1.0015 \\
GDP growth & $1.1649^{*}$ & $1.0882^{* *}$ \\
Capital account openness & 0.8974 & $1.1992^{*}$ \\
Reserves & 1.0002 & 0.9962 \\
World GDP & 0.8276 & 0.7934 \\
\hline $\mathrm{N}$ & 35 & 32 \\
Prob> chi^2 & 0.0612 & 0.0012 \\
\hline
\end{tabular}

Notes:

1. Model 1: Explanatory variables are five year averages leading to a crisis Model 2 : Explanatory variables are annual data at the onset of a crisis

2. Hazard ratios after survival analysis are reported:

3. * $p<0.05,{ }^{* *} p<0.01,{ }^{* * *} p<0.001$ 


\section{Appendix V : List of Countries in the Main Sample}

\begin{tabular}{|c|c|c|c|}
\hline \multicolumn{3}{|c|}{ Crisis countries } & \multirow{2}{*}{$\begin{array}{l}\text { Non-crisis countries } \\
\text { Austria }\end{array}$} \\
\hline Albania & India & Morocco & \\
\hline Algeria & Indonesia & New Zealand & Belgium \\
\hline Argentina & Ireland & Nigeria & Hong Kong SAR, \\
\hline Armenia & Israel & Norway & Netherlands \\
\hline Australia & Italy & Pakistan & Singapore \\
\hline Bosnia and Herzegovina & Jamaica & Panama & Slovak Republic \\
\hline Brazil & Japan & Peru & United States \\
\hline Bulgaria & Jordan & Philippines & China \\
\hline Canada & Guatemala & Poland & Estonia \\
\hline Chile & Hungary & Portugal & Lebanon \\
\hline Colombia & Iceland & Romania & Saudi Arabia \\
\hline Costa Rica & India & Russia & \\
\hline Croatia & Indonesia & Serbia & \\
\hline Czech Republic & Ireland & Slovenia & \\
\hline Denmark & Israel & South Africa & \\
\hline Dominican Republic & Italy & Spain & \\
\hline Ecuador & Jamaica & Sri Lanka & \\
\hline Egypt & Japan & Sweden & \\
\hline El Salvador & Jordan & Switzerland & \\
\hline Finland & Kazakhstan & Thailand & \\
\hline France & Kenya & Tunisia & \\
\hline Georgia & Korea, & Turkey & \\
\hline Germany & Latvia & Ukraine & \\
\hline Greece & Lithuania & United Kingdom & \\
\hline Guatemala & Macedonia & Uruguay & \\
\hline Hungary & Malaysia & Venezuela & \\
\hline Iceland & Mexico & Vietnam & \\
\hline
\end{tabular}

